\title{
Genetic Architecture for Seed Yield and it's Contributing Traits in Cowpea (Vigna unguiculata L. Walp)
}

\author{
P. B. Wadikar, M. R. Magar*, S. J. Sonawane and S. L. Dhare \\ College of Agriculture, Latur, Vasantrao Naik Marathwada Krishi Vidyapeeth, \\ Parbhani - 431 402(MS), India.
}

*Corresponding author

\section{A B S T R A C T}

\begin{tabular}{l} 
Key w or d s \\
$\begin{array}{l}\text { RAPD, genetic } \\
\text { diversity, and } \\
\text { cowpea. }\end{array}$ \\
\hline Article Info \\
\hline $\begin{array}{l}\text { Accepted: } \\
\text { 20 August } 2019 \\
\text { Available Online: } \\
\text { 10 September } 2019\end{array}$ \\
\hline
\end{tabular}

Random Amplified Polymorphic DNA (RAPD) Markers were use to determined the genetic variability of eight divers cowpea (Vigna unguiculata L. walp) genotypes from different eco-geographical regions of India. Total primers 40 out of there 35 could be generated DNA fragment were 1479 but were as 1159 showed polymorphic pattern with 78.34 per cent. The polymorphism was scored and used in band sharing analysis to identify genetic relationship between the genotypes. Dendrogram produced by the Unweighted Pair Group Method with Arithmetic Mean (UPGMA) based on Jaccard's similarity coefficient determine two groups. Similarity indices were ranging from 0.423 to 0.739 . The highest similarity coefficient was observed between genotypes GC-3 and GC-4 indicated the less divergence between them or were found to be 100 per cent similar based on molecular analysis, but could not consider as duplicate due to used less number of primers with observed lowest similarity between genotypes GC-6 and Gangotri indicating more divergent. Our result suggested that, RAPD molecular markers data are efficient for measuring genetic diversity and relatedness and also aid in selection of diverse outstanding lines to be used in future breeding programs of cowpea.

\section{Introduction}

Cowpea (Vigna unguiculata L. Walp) is one of the most important dry grains, green edible pods and leaves for vegetable as well as fodder crops. Cowpea fits well in a variety of cropping system and is grown as cover crop, mixed crop, catch crop and green manure crop, native of West Africa and India as the primary centre of origin (Vavilov, 1951) while, China is considered as secondary centre of origin. Cowpea belongs to the order Rosales, family Fabaceae and the genus Vigna. It is a diploid species with somatic chromosome number $2 \mathrm{n}=22$ (Darlington and Wylie, 1955). The major cowpea growing countries in the world are Nigeria, Burkina Faso, Ghana, Kenya, Malawi, Tanzania, Uganda (all countries in Africa), India, Sri Lanka, Burma, Bangladesh, Philippines, Indonesia and Thailand. Cowpea is low growing, vigorously bushy or trailing annual 
herbs. It is drought resistant crop and fully suitable for low fertile soil. During the last few years, the characterization and evaluation of genetic diversity and relationship within genotypes and species were performed generally using molecular techniques

\section{Materials and Methods}

\section{Plant material}

The materials included in the study consisted of eight varieties of (Vigna unguiculata L. Walp) of different origin. Entries were shown during Kharif, 2018 at Experimental farm Department of Agricultural Botany, College of Agriculture, Latur. Young and healthy leaves were collected separately from all eight genotypes of 20 to 30 days old plant

\section{Molecular analysis}

For the extraction of the genomic DNA, from each genotype 2-3 young fully expanded leaves were collected and grinded in liquid nitrogen using pestle and mortar. About $1 \mathrm{gm}$ of the grinded tissue was transferred in $2 \mathrm{ml}$ sterilized eppendrof tube. DNA isolation and purification was carried out using modified cetryl-tetramethyl ammonium bromide (CTAB) method as suggested by Saghai Maroof et al., (1984) with minor modifications. RAPD amplification was performed as described by Williams et al., (1990). The PCR amplification were carried out in a total reaction volume of $20 \mathrm{ul}$ containing 1X Assay buffer $2 \mathrm{mM} \mathrm{MgCl} 2$, $0.2 \mathrm{mM}$ dNTP, 1 picomol primer, 25-30 ng of genomic DNA and 1U Taq DNA Polymerase and visualized by ultraviolet illumination after staining with ethidium bromide.

\section{Data analysis}

The banding patterns generated by RAPD rimers were examined to determine the level of polymorphism and the genetic relationship among the cowpea parental genotypes. The presence of band at an amplicon level was scored as ' 1 ' and its absence as ' 0 '. The binary data was analyzed using standard procedure in NTSYS-PC (Version 2.1; Exeter Biological Software, Setauket, NY) software package (Rohlf, 1998). The data were subjected to the SIMQUAL option to obtain association coefficients using Jaccard's coefficient of similarity to generate a similarity matrix. Clustering analysis was performed with the unweighted pair-group method using arithmetic averages (UPGMA) in the SAHN (sequential, agglomerative, hierarchical and nested clustering method) module of NTSYSPC.

\section{Results and Discussion}

\section{Marker polymorphism}

The amplification profiles of the eight cowpea parental genotypes produced by the analysis of binary data showed that 40 random primers were produced total number of 1479 DNA fragments and among this 1159 showed polymorphic pattern with a mean value of polymorphism across the 35 primers were 78.36 per cent.(Table 1 and Fig. 1).

The percentage of polymorphism across the cowpea genotypes varied from 31.57 to 100 per cent, with an average of total number of DNA fragments per primer was 36.97 and average number of polymorphic DNA fragments per primer was 33.11.

The primer, OPA-1 and OPA-18 gave 100 per cent polymorphism but with less number of DNA fragments. The primer RPI-17 showed lowest per cent of polymorphism (31.57\%) followed by OPA-8 (33.33\%) and OPA-9 $(38.46 \%)$ while primers, viz., RPI-14, RPI-19, OPA-4, OPA-14 and OPA-17 were monomorphic. 
Table.1 Scorable DNA fragments generated by different random decamer primers through PCR in parental lines of Cowpea (Vigna unguiculata L.)

\begin{tabular}{|c|c|c|c|c|}
\hline Sr. No. & Name of primers & $\begin{array}{c}\text { No. of DNA } \\
\text { fragments produced }\end{array}$ & $\begin{array}{l}\text { No. of polymorphic } \\
\text { fragments }\end{array}$ & $\begin{array}{c}\text { Polymorphism } \\
(\%)\end{array}$ \\
\hline 1 & RPI 1 & 47 & 47 & 100.00 \\
\hline 2 & RPI 2 & 44 & 36 & 81.81 \\
\hline 3 & RPI 3 & 48 & 40 & 83.33 \\
\hline 4 & RPI 4 & 47 & 39 & 82.79 \\
\hline 5 & RPI 5 & 46 & 46 & 100.00 \\
\hline 6 & RPI 6 & 48 & 48 & 100.00 \\
\hline 7 & RPI 7 & 41 & 41 & 100.00 \\
\hline 8 & RPI 8 & 39 & 39 & 100.00 \\
\hline 9 & RPI 9 & 46 & 46 & 100.00 \\
\hline 10 & RPI 10 & 47 & 47 & 100.00 \\
\hline 11 & RPI 11 & 40 & 40 & 100.00 \\
\hline 12 & RPI 12 & 40 & 32 & 80.00 \\
\hline 13 & RPI 13 & 40 & 32 & 80.00 \\
\hline 14 & RPI 14 & 32 & 0 & 00.00 \\
\hline 15 & RPI 15 & 37 & 37 & 100.00 \\
\hline 16 & RPI 16 & 35 & 35 & 100.00 \\
\hline 17 & RPI 17 & 38 & 14 & 31.57 \\
\hline 18 & RPI 18 & 26 & 18 & 69.23 \\
\hline 19 & RPI 19 & 32 & 0 & 00.00 \\
\hline 20 & RPI 20 & 44 & 44 & 100.00 \\
\hline 21 & RPI 21 & 38 & 38 & 100.00 \\
\hline 22 & RPI 22 & 42 & 42 & 100.00 \\
\hline 23 & RPI 23 & 41 & 41 & 100.00 \\
\hline 24 & RPI 24 & 42 & 34 & 80.95 \\
\hline 25 & RPI 25 & 42 & 42 & 100.00 \\
\hline 26 & OPA 1 & 25 & 25 & 100.00 \\
\hline 27 & OPA 2 & 36 & 28 & 77.77 \\
\hline 28 & OPA 3 & 39 & 39 & 100.00 \\
\hline 29 & OPA 4 & 16 & 0 & 00.00 \\
\hline 30 & OPA 5 & 18 & 10 & 55.55 \\
\hline 31 & OPA 6 & 31 & 23 & 74.19 \\
\hline 32 & OPA 7 & 51 & 27 & 52.94 \\
\hline 33 & OPA 8 & 36 & 12 & 33.33 \\
\hline 34 & OPA 9 & 39 & 15 & 38.46 \\
\hline 35 & OPA 10 & 33 & 25 & 75.75 \\
\hline 36 & OPA 13 & 34 & 34 & 100.00 \\
\hline 37 & OPA 14 & 32 & 0 & 0.00 \\
\hline 38 & OPA 16 & 35 & 35 & 100.00 \\
\hline 39 & OPA 17 & 24 & 0 & 0.00 \\
\hline \multirow[t]{2}{*}{40} & OPA 18 & 8 & 8 & 100.00 \\
\hline & Total & 1479 & 1159 & 78.36 \\
\hline
\end{tabular}


Table.2 Similarity of parental lines of cowpea (Vigna unguiculata L.) based on NTYSIS-pc coefficient value obtained from RAPD marker data.

\begin{tabular}{|l|l|l|l|l|l|l|l|l|}
\hline Parents & $\begin{array}{l}\text { Arka } \\
\text { Garima }\end{array}$ & $\mathbf{U V - 5}$ & $\begin{array}{l}\text { Pusa } \\
\text { Komal }\end{array}$ & Gangotri & GC-6 & GDVC-2 & GC-3 & GC-4 \\
\hline $\begin{array}{l}\text { Arka } \\
\text { Garima }\end{array}$ & 1.000 & & & & & & \\
\hline UV-5 & 0.557 & 1.00 & & & & & \\
\hline Pusa Komal & 0.525 & 0.554 & 1.00 & & & & \\
\hline Gangotri & 0.521 & 0.572 & 0.510 & 1.00 & & & \\
\hline GC-6 & 0.525 & 0.510 & 0.485 & 0.423 & 1.00 & & \\
\hline GDVC-2 & 0.532 & 0.532 & 0.492 & 0.518 & 0.630 & 1.00 & \\
\hline GC-3 & 0.503 & 0.518 & 0.500 & 0.525 & 0.528 & 0.644 & 1.00 \\
\hline GC-4 & 0.532 & 0.539 & 0.492 & 0.496 & 0.521 & 0.630 & 0.739 \\
\hline Max. & 0.557 & 0.572 & 0.510 & 0.525 & 0.630 & 0.644 & 0.739 \\
\hline Mini. & 0.503 & 0.510 & 0.485 & $\mathbf{0 . 4 2 3}$ & 0.521 & 0.630 & 1.00 \\
\hline
\end{tabular}


Fig.1 DNA fingerprinting of parental lines of cowpea (Vigna unguiculata L.) by using RAPD markers

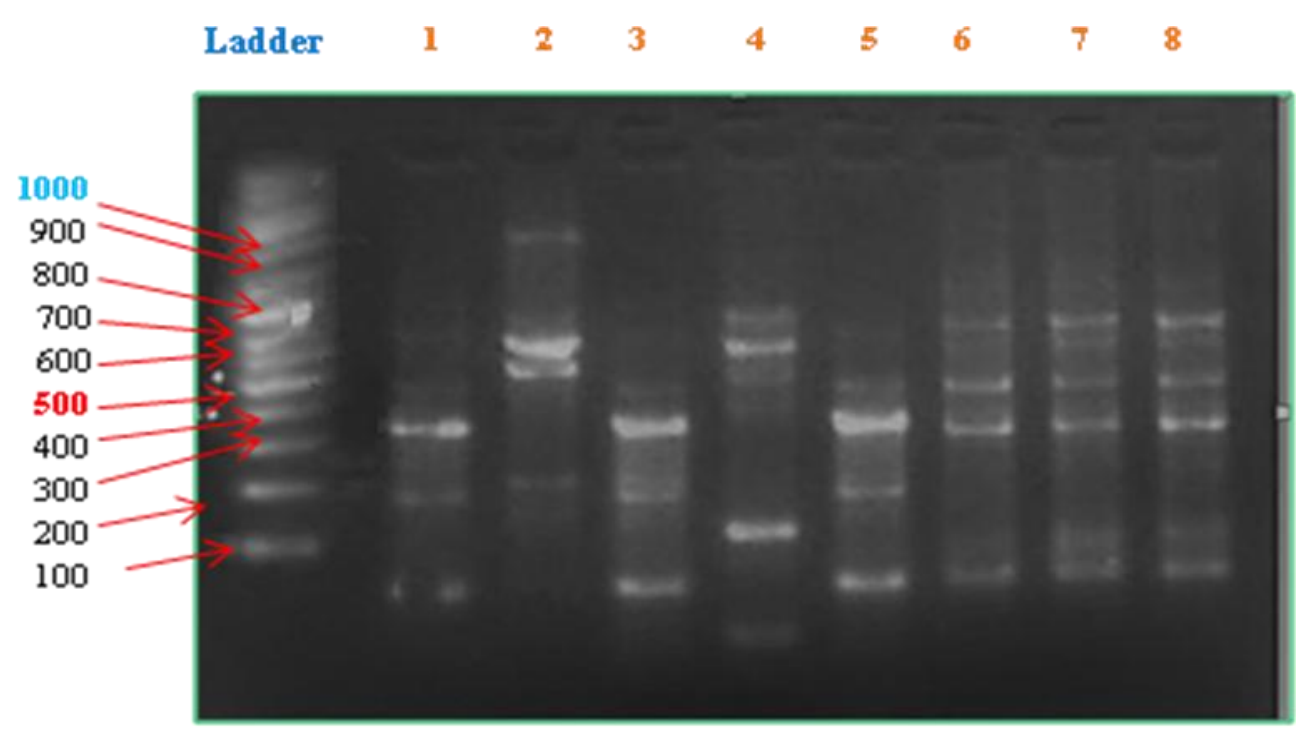

RPI-11

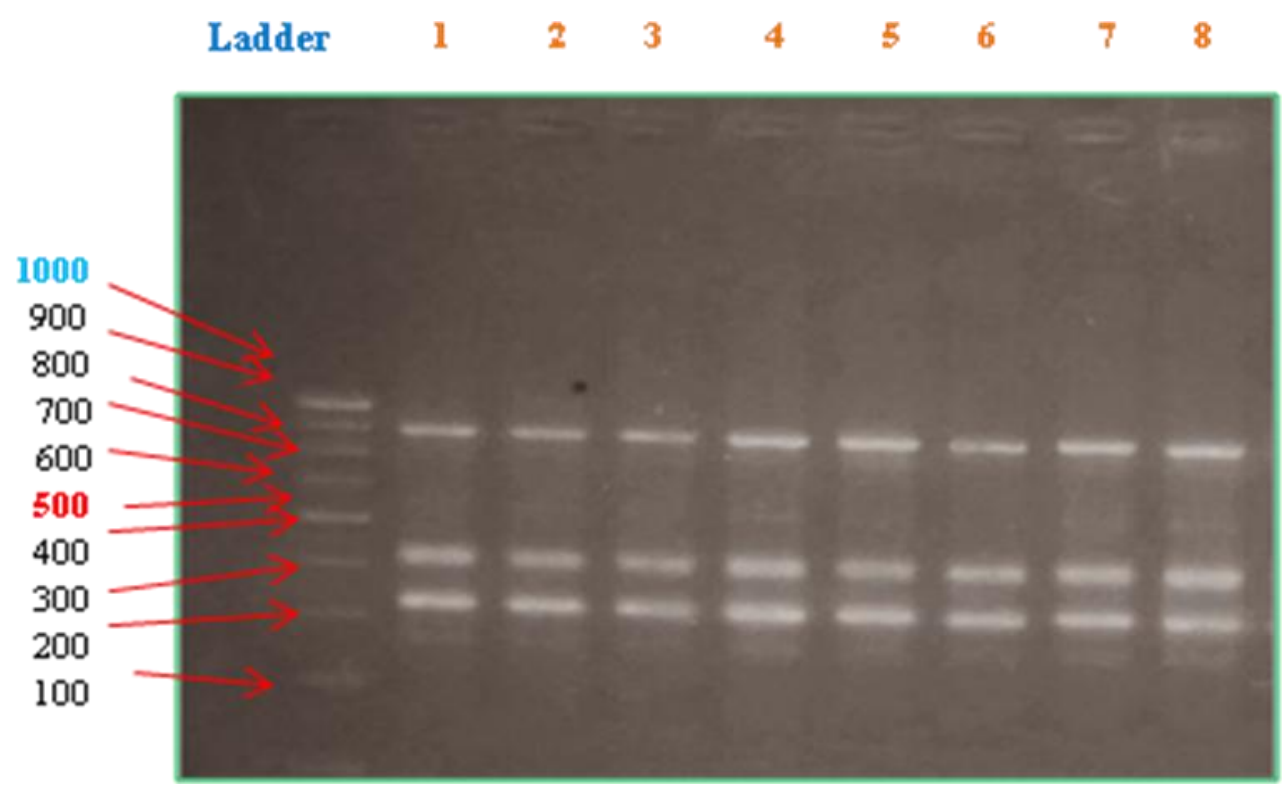

OPA -07 
Fig.2 Dendrogram for parental lines of cowpea (Vigna unguiculata L. )based on NTYSIS-pc UPGMA clustering method with genetic similarity from genoimic DNA of RAPD marker data.




Pandeay et al., (2004) also investigated 46.5 per cent polymorphism amongst 130 cowpea genotypes by using 64 random decamer primers. Patil et al., (2013) detected 73.34 per cent polymorphism in thirty accession using 20 RAPD primers whereas; Khan et al., (2015) reported 55 per cent of polymorphism among the six different cowpea genotypes. Thus, these findings support the results obtained in present research programme.

\section{Cluster analysis}

The investigation of true genetic diversity between individuals using molecular markers is an important and decisive point for clustering which provides visual idea with more information about variability presented in studied genotypes in addition to assuring the continued genetic improvement. Jaccard's pair wise similarity coefficient values generated using pooled data of 40 RAPD primers for eight cowpea genotypes. Obvious those parental lines of (Vigna unguiculata L. walp) viz., GC-3 and GC-4 showed highest similarity (0.739). On the other hand, least similarity of 0.423 was reported by GC- 6 and Gangotri and followed by (0.485) GC-6 and Pusa Komal. Such a trend of least similarity between genotypes of (Vigna unguiculata L. Walp) was also reported by Patil et al., (2015) and Wadikar et al., (2017). Further, all the eight parental genotypes showed diversity among themselves indicating that there is a considerable amount of variation which can be exploited through appropriate breeding programme. Dendrogram generated by UPGMA clustering pattern of eight genotypes using RAPD markers (Fig. 2) ranges the similarity coefficient from 0.423 to 0.739 . The dendrogram clearly revealed two clusters named as cluster $\mathrm{A}$ and cluster B having similarity coefficient 0.51 . the four out of eight cowpea of cultivars fell in cluster A. Cluster A was sub-divided in to two subclusters, A1 and A2 having similarity coefficient 0.53 . Sub-cluster A1 had only one genotype, GC-6 while, sub-cluster A2 have three genotypes viz., GDVS-2, GC-3 and GC4. Cluster B consisted of four genotypes out of which GC-3 and GC-6 highest (0.739) genetic similarity earlier, similar clustering pattern were also obtained by Pandeay et al., (2004), Patil et al., (2015) and Pradeepkumar et al., (2017).

In the present study, however genotypes GC-3 and GC-4 were found to be 100 per cent similar based on molecular analysis, but could not be considered as duplicates. It may be due to narrowness of the genetic base of widely grown cowpea and the results may be different if large number of RAPD primers may use in the study. The present study suggested that, with the help of clustering pattern and genetic relationship, breeder can identify the diverse genotype with least similarity from clusters and employ them in the future breeding programmes of cowpea. The molecular characterization of these genotypes based on RAPD is faster, less expensive and more reliable.

\section{References}

Darlington, C. D. and Wylie, A. P. (1955). Chromosome Atlas of flowering plants, George Allen and Unwin, London, pp. 132-134

Khan, M. D., Touhiduzzaman Reza, M D., Obayedul, H., Khan, M. D. Anisuzzaman, H. and Shaidul, I. (2015). Genetic diversity analysis of cowpea by RAPD markers. Inn. space of Sci. R. J., 10(2): 459-465.

Pandeay, R. N., Dhanasekar P. and Souframanien J. (2004). RAPD based DNA fingerprinting and analysis of genetic diversity in radiation induced mutants of cowpea (Vigna unguiculata L. Walp.). Ind. J. Genetics., 64(2): 97101. 
Patil, D. M., Sawardekar, S. V., Gokhale, N. B., Bhave, S. G., Sawant, S. S., Sawantdesai, S. A., Lipne, K. A., Sabale, S. N. and Joshi, S. N. (2013). Genetic diversity analysis in cowpea (Vigna unguiculata L. Walp.) by using RAPD markers. Int. J. of Inno. Biotec. and Biochemistry, 1(1): 15-23.

Patil, V., Sharma S., Kalaskar, S., Kachare S. and Dapke, J. (2015). Assessment of diversity among cowpea (Vigna unguiculata L. Walp) genotypes based on RAPD analysis. Ele. J. of Plant Breeding, 6(2): 403-411.

Pradeepkumar, T., Deepu M,, Varun, R., C., Veni, K. and Midhila, K. R. (2017). Genetic interrelationship among cowpea varieties elucidated through morphometric, RAPD and SSR analyses. Legume Res., 40(3): 409-415.

Rohlf, F. J. (1998). NTSYS - PC: Numerical Taxonomy and Multivariate Analysis System. Version 2.01 Exeter software: Setauket, New York. pp. 1-38.

Vavilov N. I. (1939). Genetics in the USSR. Chronica Botanica, 5(1):14-15.

Wadikar, P. B., Solanki, B. G., Patel, D. H., and Narwade, A. V. (2017). RAPDBased assessment of genetic diversity in upland cotton (Gossypium hisutum L.). Multilogic in science, 6(XIX):22777601

Williams, J.G.K., Kubelik, A.R., Rafalski, J.A. and Tingey, S.V. (1990). DNA polymorphism amplified by arbitrary primers are useful as genetic markers. Nucleic Acid Res., 18, 6231-6235.

\section{How to cite this article:}

Wadikar, P. B., M. R. Magar*, S. J. Sonawane and Dhare, S. L. 2019. Genetic Architecture for Seed Yield and it's Contributing Traits in Cowpea (Vigna unguiculata L. Walp). Int.J.Curr.Microbiol.App.Sci. 8(09): 1850-1857. doi: https://doi.org/10.20546/ijcmas.2019.809.214 